\title{
Analysis of Vegetation Structure of Castanopsis sieboldii Forest in the Warm-temperate Zone, Korea
}

\author{
Sung-Je Lee*, Keiichi Ohno, Jong-Suk Song" \\ Graduate school of Environment and Information Sciences, Yokohama National University, \\ Yokohama 240-8501, Japan \\ ${ }^{1)}$ Department of Biological Science, Andong National University, Andong 760-749, Korea \\ (Manuscript received 21 December, 2011; revised 4 January, 2012; accepted 22 February, 2012)
}

\begin{abstract}
This study aims at classifying and analyzing the vegetation structure of Castanopsis sieboldii forest, one of the evergreen broad-leaved forests found under the warm-temperate climate of Korea. It is also compared with the ones of the Castanopsis sieboldii forest in Japan where most similar such forest of Korea, to find unique vegetation structures of the only Korean forest. Vegetation structure of Korean Castanopsis sieboldii forest was divided into two units at the level of community units both of Ardisia japonica-Castanopsis sieboldii community and Ardisio-Castanopsietum sieboldii association. The association carries similar type with the vegetation system of Japan, but any subunits differentiated with the Japan were found vary much. Hierarchical cluster analysis brings in similar result with the analysis on the vegetation structure as well.
\end{abstract}

Key Words : Phytosociology, Evergreen broad-leaved forest, Jeju, Wando, Classification, Japan

\section{Introduction}

It conducted that the studies on the evergreen broad-leaved forests of the islands in the Korean Peninsula and Jeju-do Island in their flora and phytosociological studies (Kim, 1991, Kim and Oh, 1990, 1991; Park, 2007) and the studies on the vegetation structures (Han et al., 2007; Oh and Choi, 1993; Oh, 1994; Oh et al., 2007). Most of their studies were limited to analyzing the vegetation structures only by areas or their analysis was obtained by selecting only the trees, and very few data and information on analyzing the vegetation structures of the whole country are found. In particular, investigation on the vegetation structure of

"Corresponding author : Sung-Je Lee, Graduate school of Environment and Information Sciences, Yokohama National University, Yokohama 240- 8501, Japan

Phone: +81-45-339-4375

E-mail: phytoeco@gmail.com the Castanopsis sieboldii is insufficient.

This study, therefore, aims at analyzing and classifying the structure of Castanopsis sieboldii forest among the evergreen broad-leaved forests distributed in the warm-temperate zone of Korea. In addition, differences of the evergreen broad-leaved forests in Japan showing high similarity with the forests on the Korean peninsula were compared and analyzed. At the same time this study was conducted to collect and provide basic data and information required to analyze the vegetation structures of the peninsula as a whole.

\section{Materials and methods}

\subsection{Climate}

Most of the Korean peninsula is dominated by the deciduous broad-leaved forest in the temperate zone. That is to say, those are the regions of humid cool-temperate climate with significant frost every 
year and occasional temperatures significantly below $-15{ }^{\circ} \mathrm{C}$, but the southernmost Korea and Jeju-do island are usually covered by evergreen broad-leaved forests in the warm-temperate zone, with light-tomoderate frost ever or nearly every year and absolute minima not under $-15{ }^{\circ} \mathrm{C}$ (usually, leaf-changing seasonal broad-leaved evergreen forests can be tolerant and subtropical evergreen forests may not be) (Kolbek et al., 2003). This also includes the zones recognized on mid-latitude continental east sides by most global climate classification systems (Bailey, 1990; Walter and Box, 1976; Walter, 1984). This climate zone is also distributed in southern China. The study sites belong to the warm-temperate zone.

\subsection{Study area}

The studies were carried out at Castanopsis sieboldii forest of evergreen broad-leaved forest on Jeju-do Island and Southern islands, South Korea. The detail study sites are Bogil-do, Jin-do, Oinaro-do, Soan-do, and Wan-do Islands in the Korean peninsula and Mt. Sanbansan, Seonheul-ri, Eastern Gotjawal, and Gotjawal (Mt. dongbakdongsan) in Jeju-do Island. Fig. 1 shows the location of quadrates and topography of the study sites.

The field works carried out from 2005 to 2009.

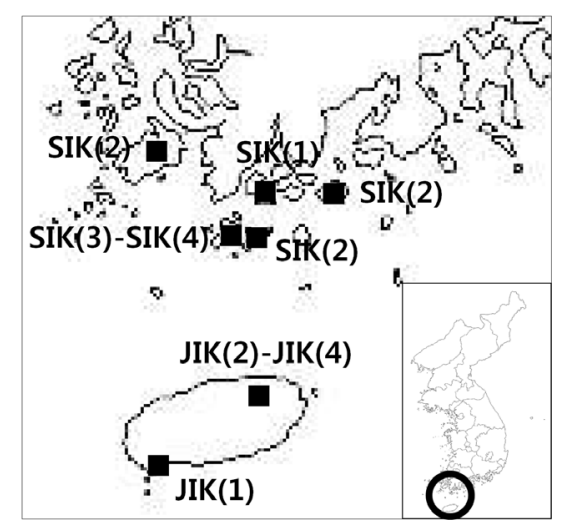

Fig. 1. Location of study sites. SIK(1)-JIK(4) : study sites (refer to Table 1)

\subsection{Vegetation research and analysis}

Relevés were sampled in the typical evergreen broad-leaved forest, according to the Braun-Blanquet approach (Braun-Blanquet, 1964). The relevé sizes were set in such a way as to represent a vegetation's full floristic composition, from $120 \mathrm{~m}^{2}$ to $500 \mathrm{~m}^{2}$. All of relevés were taken from floristically and physiognomically on homogeneous stands. Data storage and a table work were carried out according to the phytosociological approach for vegetation classification (Mueller-dombois and Ellenberg, 1974). The relevés were classified and documented in a synoptic table. All vascular plants were recorded. An elevation, geographical coordinates, a slope aspect and a slope inclination were recorded at each relevé site. Scientific names of the plants investigated followed BGplants(2011) and Korean Plant Names Index (2007).

\subsection{Hierarchical cluster analysis}

Hierarchical cluster analysis on the Relevé groups (study sites) estimated the similarities between the relevés after the constancy values were quantified by Yanai et al.(2007) and then group average method (UPGMA) based on the Bray-Curtis dissimilarity coefficient was applied to the analysis by the software of SYN-TAX 2000 (Podani, 2001). The estimation was made excluding companion species of floristic components that does not affect community classification.

\section{Result}

\subsection{Vegetation analysis}

Phytosociological table manipulation was applied to the field survey data, resulting in dividing broadly into one community and one association. The association was classified into 3 subassociations including typical subassociation and some of the subassociations were classified into 4 variants including typical variant (Table 1). 
Table 1. Synoptic table of the communities of Castanopsis sieboldii forest in South Korea

\begin{tabular}{|c|c|c|c|c|c|c|c|c|c|}
\hline \multirow{4}{*}{$\begin{array}{l}\text { Class } \\
\text { Order and alliance } \\
\text { Association and community } \\
\text { Subassociation }\end{array}$} & \multicolumn{9}{|c|}{ Camellietea japonicae } \\
\hline & & & \multicolumn{7}{|c|}{ Quercion acuto-mysinaefoliae and Illicio-Quercetalia acutae } \\
\hline & \multirow{3}{*}{\multicolumn{2}{|c|}{\begin{tabular}{|l|} 
Ardisia japonica- \\
$\quad$ Castanopsis sieboldii
\end{tabular}}} & \multicolumn{7}{|c|}{ Ardisio-Castanopsietum sieboldii } \\
\hline & & & \multirow[t]{2}{*}{ Typical } & \multicolumn{3}{|c|}{ Quercetosum acutae } & \multicolumn{3}{|c|}{$\begin{array}{l}\text { Arachniodo- } \\
\qquad \text { Quercetum salicinae f. angustata }\end{array}$} \\
\hline Variant & & & & Typical & $\begin{array}{l}\text { Pourt } \\
\text { villosc } \\
\text { vill }\end{array}$ & $\begin{array}{l}\text { thiaea } \\
\text { sa var. } \\
\text { llosa }\end{array}$ & $\begin{array}{l}\text { Mallotus } \\
\text { japonicus }\end{array}$ & & \\
\hline Serial number & 1 & 2 & 3 & 4 & & 5 & 6 & 7 & 8 \\
\hline Study sites & $\operatorname{SIK}(1)$ & $\operatorname{SIK}(2)$ & $\operatorname{JIK}(1)$ & $\operatorname{SIK}(3)$ & & $\mathrm{K}(4)$ & $\operatorname{JIK}(2)$ & JIK(3) & JIK(4) \\
\hline Slope inclination $\left({ }^{\circ}\right)$ & $20-35$ & $15-25$ & $30-42$ & $5-23$ & & 6-28 & 0 & $0-5$ & $0-10$ \\
\hline Altitude (m) & $10-20$ & $30-120$ & $365-390$ & $50-85$ & & -315 & $187-250$ & $196-230$ & $160-219$ \\
\hline Average no. of spp. & 19 & 31 & 20 & 24 & & 31 & 39 & 29 & 27 \\
\hline No. of releves & 5 & 10 & 6 & 5 & & 5 & 6 & 6 & 7 \\
\hline \multicolumn{10}{|c|}{$\begin{array}{l}\text { Character and differential species of Ardisio-Castanopsietum sieboldii Suz.-Tok. Et Hatiya } 1952 \\
\end{array}$} \\
\hline Castanopsis sieboldii & V 5 & V 4-5 & V 5 & V 2-5 & V & $1-5$ & V 2-5 & V 4-5 & $\mathrm{V}+-2$ \\
\hline Cymbidium goeringii & $I+$ & III + & $\Pi+$ & II + & $\mathrm{V}$ & + & $\mathrm{I}+$ & $I+$ & \\
\hline Dryopteris bissetiana & $I+$ & $\mathrm{V}+-2$ & & $I+$ & III & +-1 & $I+$ & & $I+$ \\
\hline Callicarpa mollis & & IV +-1 & & & III & +-2 & $\mathrm{I}+$ & II +-1 & \\
\hline Viburnum erosum & & III +-2 & & $\mathrm{I}+$ & IV & + & & & \\
\hline \multicolumn{10}{|l|}{ Differential species of Subunit(1) } \\
\hline Dryopteris pacifica & & & & $\mathrm{IV}+$ & I & + & & & \\
\hline Pinus densiflora & & & & III 1 & ПI & 1 & & & \\
\hline Quercus acuta & & +1 & & IV +-2 & $\mathrm{~V}$ & $2-4$ & & & I 1 \\
\hline \multicolumn{10}{|l|}{ Differential species of Subunit(1-1) } \\
\hline Pourthiaea villosa var. villosa & & $I+$ & & & & +-1 & & & \\
\hline Benthamidia japonica & & & II $1-2$ & $I+$ & & + & & & \\
\hline Carpinus laxiflora & & & & & & 1 & & & \\
\hline Daphniphyllum macropodum & & & & & II & $1-2$ & & & \\
\hline Dryopteris chinensis & & & & & & + & & & \\
\hline \multicolumn{10}{|l|}{ Differential species of Subunit(2) } \\
\hline Quercus glauca & & & & & & & III +-2 & III 1 & III $1-2$ \\
\hline Arachniodes aristata & & & & & & & $\mathrm{V} \quad 1-3$ & $\mathrm{~V}+-2$ & V 2-3 \\
\hline Damnacanthus indicus & & & & & & & $\mathrm{I}+$ & III + & III +-1 \\
\hline Calanthe discolor & & & & & & + & III + & $\Pi+$ & II +-1 \\
\hline \multicolumn{10}{|l|}{ Differential species of Subunit(2-1) } \\
\hline Cyrtomium fortunei & & & & & & & III +-1 & & \\
\hline Polystichum lepidocaulon & & & & & & & $\Pi+$ & & \\
\hline Mallotus japonicus & & & $I+$ & & & + & IV +-1 & & \\
\hline Dryopteris uniformis & & & & $I+$ & & & II +-1 & & \\
\hline \multicolumn{10}{|c|}{ Character and differential species of Quercion acuto-mysinaefoliae K. Fujiwara 1981 and Illicio-Quercetalia acutae K. Fujiwara 1981} \\
\hline Neolitsea aciculata & & & $\mathrm{V}+-2$ & II + & IV & +-2 & $\mathrm{~V}+-1$ & $\mathrm{~V}+$ & $\mathrm{V}+-1$ \\
\hline Machilus japonica & & & III + & III +-1 & & + & $\mathrm{V}+-1$ & $\mathrm{~V}+-1$ & $\mathrm{~V}+-1$ \\
\hline Styrax japonica & & $I+$ & $\mathrm{I}+$ & I 1 & & & II +-1 & I 1 & III +-1 \\
\hline Ophiopogon japonicus & & & $\mathrm{I}+$ & $\mathrm{I}+$ & & {$[+$} & $\mathrm{V}+-2$ & III +-1 & $\mathrm{~V}+$ \\
\hline Acer palmatum & & ++ & & I 1 & & & III +-1 & II 1 & $\Pi+$ \\
\hline Distylium racemosum & & & $\mathrm{V}+-1$ & & I & 1 & IV +-2 & $\mathrm{~V}+-2$ & $\mathrm{~V}+-2$ \\
\hline Ardisia crenata & & & $\mathrm{IV}+$ & III + & & & $\mathrm{V}+$ & $\mathrm{V}+$ & $\mathrm{V}+-1$ \\
\hline Quercus salicina f. angustata & & I 1 & & V $2-4$ & П & $1-2$ & V $1-4$ & $\mathrm{~V} 1-3$ & $\mathrm{~V}$ 4-5 \\
\hline \multicolumn{10}{|c|}{ Vegetation components of Southem islands in the Korean peninsula } \\
\hline Pittosporum tobira & $\mathrm{IV}+$ & II + & & & & & & & \\
\hline Rhaphiolepis indica var. umbellata & V $1-2$ & II +-1 & & $\mathrm{I}+$ & I & + & & & \\
\hline Liriope muscari & $\mathrm{V}+-1$ & II +-1 & & & & & & & \\
\hline Farfugium japonicum & & $\Pi+$ & & & & & & & \\
\hline Cyrtomium falcatum & $I+$ & & & & & & & & \\
\hline Quercus serrata & II +-1 & II 1 & & I 1 & & & & & \\
\hline Oplismenus undulatifolius var. undulatifolius & & III +-1 & & & & & & & \\
\hline Carex lenta & & III + & & & I & + & & & \\
\hline
\end{tabular}


Character and differential species of Camellietea japonicae Miyawaki et Ohba 1963

\begin{tabular}{|c|c|c|c|c|c|c|c|c|}
\hline Eurya japonica & $\mathrm{IV}+$ & $\mathrm{V}+-3$ & $\mathrm{~V}+-3$ & $\mathrm{~V}+-1$ & $\mathrm{~V}+-2$ & IV +-1 & $\mathrm{~V}+-1$ & $\mathrm{~V}+-1$ \\
\hline Trachelospermum asiaticum & V $2-4$ & $\mathrm{~V}+-3$ & $\mathrm{~V}+-1$ & IV +-1 & $\mathrm{~V}+-1$ & $\mathrm{~V}+-2$ & $\mathrm{~V}+-1$ & $\mathrm{~V}+-2$ \\
\hline Camellia japonica & & $\mathrm{IV}+-3$ & V $1-3$ & V 2-3 & $\mathrm{V} \quad 1-3$ & $\mathrm{~V}+-2$ & $\mathrm{~V}+-1$ & $\mathrm{~V}+-2$ \\
\hline Ligustrum japonicum & $\mathrm{V}+-2$ & $\mathrm{~V}+-1$ & & III +-1 & $\mathrm{~V}+-2$ & $\mathrm{~V}+-1$ & $\mathrm{~V}+$ & $\mathrm{V}+-1$ \\
\hline Ardisia japonica & $\mathrm{V}+-2$ & $\mathrm{~V}+-3$ & $\mathrm{~V}+$ & $\mathrm{V}+-1$ & $\mathrm{IV}+$ & III + & $\mathrm{V}+$ & IV +-1 \\
\hline Dryopteris erythrosora & $\mathrm{I}+$ & $\Pi+-2$ & $\mathrm{~V}+-1$ & $\mathrm{~V}+-1$ & $\mathrm{~V}+-2$ & $\mathrm{~V}+-1$ & $\mathrm{~V}+-2$ & $\mathrm{~V}+-2$ \\
\hline Cinnamomum tenuifolium & $\mathrm{V}+-1$ & $\mathrm{IV}+$ & $\mathrm{V} 1-3$ & $\mathrm{~V}+-1$ & $\mathrm{~V}+-2$ & $\mathrm{~V}+-1$ & $\mathrm{~V}+-1$ & $\mathrm{~V}+-2$ \\
\hline Lemmaphyllum microphyllum & II + & $\Pi+$ & $\mathrm{V}+$ & $I+$ & $\Pi+$ & $\mathrm{IV}+$ & $\mathrm{V}+$ & $\mathrm{IV}+$ \\
\hline Neolitsea sericea & & ++ & $\Pi+$ & $I+$ & $\mathrm{V}+$ & $\Pi+-1$ & $I+$ & III + \\
\hline Machilus thunbergii & $\mathrm{V}+-2$ & $\mathrm{~V}+-2$ & $\mathrm{I}+$ & $\mathrm{V}+-1$ & III + & & II +-1 & \\
\hline Hedera rhombea & $\mathrm{I}+$ & $\mathrm{V}+-1$ & III + & $\Pi+$ & $\mathrm{I}+$ & $\mathrm{V}+-1$ & $\mathrm{~V}+$ & $\mathrm{V}+$ \\
\hline Ilex integra & $\mathrm{V} 2$ & IV $1-2$ & IV $1-2$ & III +-1 & II + & II + & II + & II + \\
\hline Kadsura japonica & & IV +-1 & $\Pi+$ & $\mathrm{V}+-1$ & $\mathrm{I}+$ & IV + & $\mathrm{V}+$ & $\mathrm{IV}+$ \\
\hline Stauntonia hexaphylla & II + & $\Pi+$ & $\mathrm{IV}+$ & $\Pi+$ & $\mathrm{V}+$ & $\mathrm{V}+$ & $\mathrm{V}+$ & III + \\
\hline Ophiopogon japonicus & $\mathrm{V}+-1$ & $\mathrm{~V}+-1$ & II + & III + & $\mathrm{V}+$ & $I+$ & $I+$ & III + \\
\hline Litsea coreana & V $1-2$ & $I+$ & $\mathrm{I}+$ & II 1 & IV +-1 & II +-1 & III + & ПI 1 \\
\hline Ficus nipponica & IV + & II +-1 & $\mathrm{~V}+$ & $\Pi+$ & III + & $\mathrm{V}+-1$ & IV + & $I+$ \\
\hline Elaeagnus glabra & IV +-1 & $\Pi+$ & & $I I+$ & $\mathrm{I}+$ & III + & $\mathrm{IV}+$ & III + \\
\hline Liriope spicata & & ++ & & & & $I+$ & & \\
\hline Cleyera japonica & & & & & & & $\mathrm{I}+$ & $\Pi+$ \\
\hline Euonymus japonicus & & ++ & $\Pi+$ & & & & & \\
\hline Daphne kiusiana & & & & & & $\Pi+$ & $I+$ & $I+$ \\
\hline Meliosma myriantha & & II + & & & & & & \\
\hline Elaeagnus macrophylla & III + & III + & $\mathrm{V}+$ & & $I+$ & & & \\
\hline Dendropanax morbiferus & $\mathrm{V} \quad 1-2$ & III $1-2$ & & III +-1 & IV +-1 & III +-1 & $\mathrm{~V}+-1$ & IV +-1 \\
\hline Meliosma oldhamii & & $I+$ & & & II +-1 & I 1 & & \\
\hline Paederia scandens var. scandens & & $\Pi+$ & & & & $\mathrm{I}+$ & $\Pi+$ & \\
\hline Asplenium incisum & $I+$ & ++ & & & & $\mathrm{IV}+$ & $\mathrm{IV}+$ & \\
\hline Rhamnella frangulioides & & & & & & $\Pi+$ & & \\
\hline Callicarpa japonica & $I+$ & III + & & & & III + & $I+$ & \\
\hline
\end{tabular}

* Study sites : SIK(1) : Wan-do island; SIK(2) : Oinaro-do, Soan-do, Jin-do islands; JIK(1) : Mt. Sanbansan, Jeju-do island; SIK(3), SIK(4) : Bogil-do island; JIK(2) JIK(3) : Seonheul-Ri, Gotjawal, Seonheul-ri, Jeju-do island; JIK(4) : Seonheul-Ri, Gotjawal(Mt. Dongbakdongsan), Eastern Gotjawal, Jeju-do island.

* Companion species (scientific name : serial number (constancy value)) : Smilax china : 1 ( I ), 2 (IV), 3 (V), 4 (III), 5 (IV), 6 (IV), 7 (II); Ficus erecta : 2 (IV), 3 (IV), 4 ( I ), 6 (V), 7 (II), 8 (II); Dioscorea tokoro : 2 (II), 4 ( I ), 5 ( I ), 6 ( I ), 7 ( I ), 8 (I ); Pyrola japonica : 1 ( I ), 2 ( I ), 4 ( I ), 5 (IV), 6 ( I ); Cocculus trilobus : 2 (+), 4 ( I ), 5 ( I ), 6 (III), 7 (II); Gardneria insularis : 3 П (), 4 ( I ), 5 ( I ), 6 (II), 7 П (); Parthenocissus tricuspidata : 2 ( I ), 4 ( I ), 6 ( I ), 7 ( I ), 8 (II); Ampelopsis brevipedunculata : 2 ( I ), 6

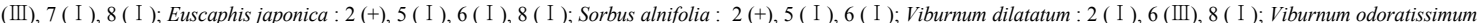
var.awabuki : 3 ( I ), 6 (III), 8 (I ); Ficus erecta var.sieboldii : 3 (II), 6 ( I ), 8 ( I ); Oplismenus undulatifolius var.japonicus : 5 ( I ), 6 ( I ), 8 ( I ); Euonymus oxyphyllus : 2 (+), 5 (II); Rhus tricocarpa : 1 (I), 2 (+); Pinus thunbergii : 1 ( I ), 2 (+); Symplocos chinensis f. pilosa : 2 (+), 4 ( I ); Fraxinus sieboldiana : 2 (+), 5 (II); Zanthoxylum piperitum : 2 $(+), 6$ (I); Dryopteris lacera : 2 (+), 6 ( I ); Albizia julibrissin : 2 (I), 8 ( I ); Carpinus tschonoskii var.eximia : 2 (+), 8 ( I ); Arisaema ringens : 3 ( I ), 6 ( I ); Cerasus leveilleana : 4 ( I ), 5 ( I ); Pyrrosia lingua : 6 (III), 7 ( I ); Loxogramme salicifolia : 6 ( I ), 7 ( I ); Pourthiaea villosa var.zollingeri : 6 ( I ), 7 ( I ); Kalopanax septemlobus : 6 (I ), 7 (I ); Xylosma congesta : 6 (II), 8 ( I ); Celtis sinensis var. japonica : 6 (II), 8 ( I ); Idesia polycarpa : 6 ( I ), 8 ( I ); Arisaema serratum : 6 ( I ), 8 ( I ); Ainsliaea apiculata : 2 (I); Desmodium podocarpum var.oxyphyllum : 2 (I); Lindera obtusiloba var.obtusiloba : 2 (I); Quercus variabilis : 2 ( I ); Pueraria lobata : 2 ( I ); Vaccinium bracteatum : 2 ( I ); Milletia japonica : 2 ( I ); Calamagrostis arundinacea var.brachytricha :2 ( I ); Lepisorus thunbergianus : 2 ( I ); Carex oahuensis var. robusta : 2 ( I ); Disporum smilacinum : $2(+)$; Acer pictum subsp.dissectum : $2(+)$; Carpinus turczaninovii : $2(+)$; Maackia amurensis var.amurensis : $2(+)$; Castanea crenata : $2(+)$; Rhododendron mucronulatum var. mucronulatum : $2(+)$; Lophatherum gracile : $2(+)$; Cephalanthera longibracteata : $2(+)$; Thalictrum actaefolium : $2(+)$; Aster scaber : $2(+)$; Phaenosperma globosa : $2(+)$; Scutellaria indica : $2(+) ;: 2(+)$; Lespedeza maximowiczii $: 2(+)$; Prunus verecunda f. tomentella $: 2(+)$; Platycarya strobilacea var. strobilacea $\mathrm{f}$. strobilacea : $2(+)$; Phryma leptostachya var. asiatica : $2(+)$; Chloranthus japonicus : $2(+)$; Lonicera morrowii : $2(+)$; Wisteria floribunda : $2(+)$; Disporum sessile var. sessile : 2 $(+)$; Lecanorchis japonica : $2(+)$; Ainsliaea acerifolia : $2(+)$; Lindera glauca var. glauca : $2(+)$; Prunus serrulata var. spontanea : $2(+)$; Galium pogonanthum $: 2(+)$; Pteridium aquilinum var. latiusculum : 2 (+); Blechnum niponicum : 2 (+); Zanthoxylum ailanthoides : 3 ( I ); Ficus thunbergii : 3 ( I ); Zanthoxylum schinifolium : 4 ( I ); Menispermum dauricum : 4 ( I ); Dryopteris nipponensis : 4 ( I ); Thelypteris acuminata : 4 ( I ); Cornus controversa : 4 ( I ); Phyllostachys edulis : 4 ( I ); Sapium japonicum : 4 ( I ); Hosta longipes var. longipes : 5 ( I ); Dioscorea nipponica : 5 ( I ); Buxus microphylla var. insularis : 5 ( I ); Celastrus orbiculatus : 6 (III); Polygonatum macranthum : 6 ( I ); Actinidia arguta var arguta : 6 (П); Ligustrum sp. : 6 (П); Rhus succedanea : 6 (П); Polystichum tsussimense : 6 (П ); Lindera ervthrocarpa : 6 (П); Cudrania tricuspidata : 6 ( $\Pi$ ); Dryopteris saxifraga : 6 ( I ); Akebia quinata : 6 ( I ); Schizophragma hydrangeoides : 6 ( I ); Celtis jessoensis : 6 ( I ); Spodiopogon sibiricus : 6 ( I ); Tylophora sp. : 6 ( I ); Asparagus schoberioides : 6 ( I ); Clerodendrum trichotomum : 6 ( I ); Cornus macrophylla : 6 ( I ); Lonicera japonica : 6 ( I ); Teucrium japonicum : 6 ( I ); Viola sieboldii : 6 ( I ); Diplazium subsinuatum : 6 ( I ); Smilax sieboldii f. sieboldii : 6 ( I ); Morus bombycis var.bombycis : 6 ( I ); Isodon inflexus : 6 ( I ); Ternstroemia gymnanthera : 7 (II); Cephalanthera falcata : 7 ( I ); Fatsia japonica : 7 ( I ); Liparis nervosa : 7 ( I ); Prunus pendula f. ascendens : 8 ( I); Orixa japonica : 8 ( I) ; Maackia amurensis var. fauriei : 8 ( I ); Polystichum tripteron : 8 ( I ); Picrasma quassioides : 8 ( I ); Quercus gilva : 8 ( I ).

* Contact to Corresponding author for Original data. 
3.1.1. Ardisia japonica-Castanopsis sieboldii community

This community appears at Wan-do Island (SIK (1)) and other islands scattered in the southern parts of Korean peninsula $(\operatorname{SIK}(2))$. It is distributed over east and west slopes around the southward aspect of slopes mostly except some relevés (such as Mira-ri in Soan-do Island, Oinaro-do Island: Northern aspect of slope). Most of it consists of brown forest soil being distributed at medium slope of $15 \sim 35^{\circ}$. At Wan-do Island, the community was distributed at relatively low altitude (10 20 m) compared with other islands (30 120 m).

Tree layer in the Ardisia japonica-Castanopsis sieboldii community was dominated by Castanopsis sieboldii and some of the character and differential species of Camellietea japonicae such as Ardisia japonica were selected as such species of this community in addition to Castanopsis sieboldii, Cymbidium goeringii, Dryopteris bissetiana, Callicarpa mollis and Viburnum erosum (Miyawaki et al., 1994). At Wan-do Island, other differential species (Cymbidium goeringii, Dryopteris bissetiana, Callicarpa mollis, Viburnum erosum) were not found except Castanopsis sieboldii or they appeared in low constancy values.

The vegetation components of Southern islands in the Korean peninsula are Pittosporum tobira, Rhaphiolepis indica var. umbellata, Liriope muscari, Farfugium japonicum, Cyrtomium falcatum, Quercus serrata, Oplismenus undulatifolius var. undulatifolius, and Carex lenta. This vegetation components show the representative vegetation of Castanopsis sieboldii forest found at the only low areas of southern islands in Korea against the Ardisio-Castanopsietum sieboldii Suz.-Tok. et Hatiya 1952 (association) in Jeju-do Island and the other southern islands in Korea.

\subsubsection{Ardisio-Castanopsietum sieboldii Suz.-Tok. Et Hatiya 1952}

This association appears at Mt. Sanbang in Jeju-do
Island (JIK (1)), Bogil-do Island (SIK(3), SIK(4)), Seonheul-ri and Gotjawal in Jeju-do Island (JIK (2), JIK(3)). This association was distributed over from flat land to various slopes according to the study sites. It is consisted mostly of brown forest soil and the soil of volcanic rocks and at various slopes ranging from $0{ }^{\circ}$ to $42^{\circ}$. Some of the relevé of $\operatorname{SIK}(3)$ and SIK (4) were found at low sea level altitude $(50-90 \mathrm{~m})$ compared with other study $\operatorname{sites}(160-390 \mathrm{~m}) \quad$ (Fig. 2). Upper unit of this association is Quercion acuto-mysinaefoliae and Illicio-Quercetalia acutae (alliance, order) and Camellietea japonicae (class). The class is also the highest unit of other community.

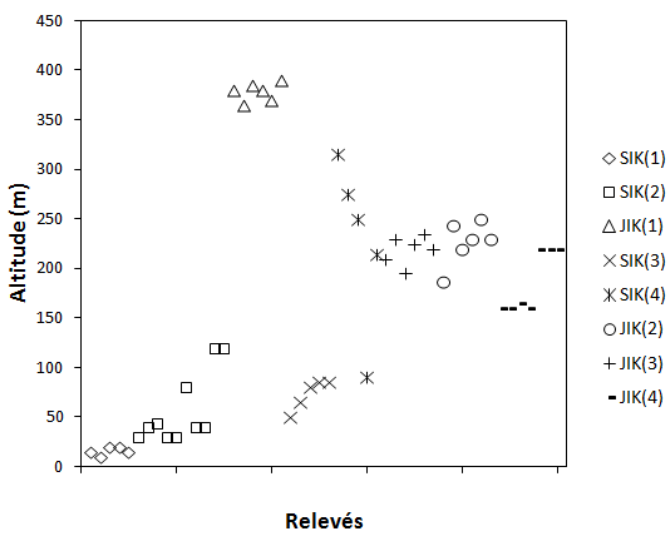

Fig. 2. Vertical distribution of each relevé in the study sites (relevé groups), South Korea.

SIK(1)-JIK(4) : study sites (refer to Table 1)

Tree layers of this Ardisio-Castanopsietum sieboldii were dominated by Castanopsis sieboldii as the case with Ardisio-Castanopsietum sieboldii of Japan (Miyawaki and Okuda, 1990) and Quercus acuta, Quercus glauca, and Quercus salicina f. angustata were found as well. In some parts of Jeju-do Island (JIK(4)), Quercus salicina f. angustata appeared in higher dominating extent in its relevé than Castanopsis sieboldii. Some of the character species and classify in species of Camellietea japonicae 
(Miyawaki et al., 1994) like Ardisia japonica were selected as such species of this community in addition to Castanopsis sieboldii, Cymbidium goeringii, Dryopteris bissetiana, Callicarpa mollis, Viburnum erosum. This association was divided into lower units such as subassociations and variants by the character species of each lower unit.

\subsubsection{Typical subassociation}

This kind of typical subassociation appears at Mt. Sanbang in Jeju-do Island. It is found at various slope aspects, rapid slope of $30-42^{\circ}$ (Fig. 3) and the slopes of the hill ridges at the highest altitudes of $365-390 \mathrm{~m}$ compared with other communities (Fig. 2). Main Character and differential species such as Dryopteris bissetiana, Callicarpa mollis, and Viburnum erosum were not found there. This subunit belongs to relatively simple structure compared with others by low appearing numbers of species in average, and it is dominated mainly by Castanopsis sieboldii on the canopy.

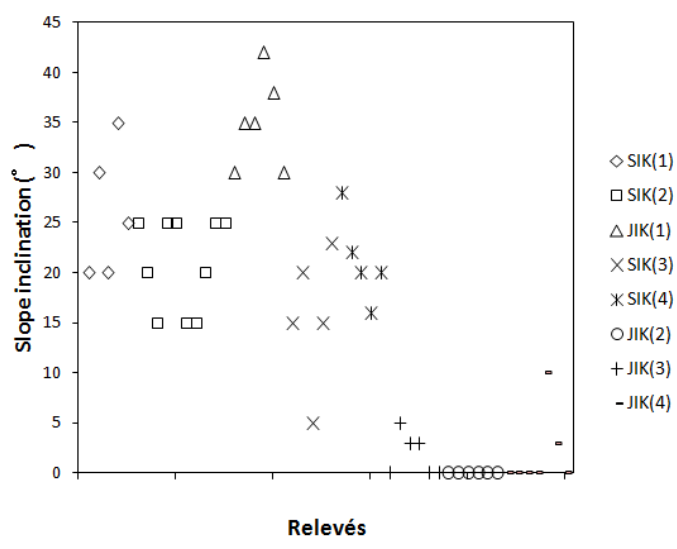

Fig. 3. Slope inclination of each relevé in the study sites (relevé groups), South Korea. SIK(1)-JIK(4) : study sites (refer to Table 1)

\subsubsection{Quercetosum acutae subassociation}

The vegetation structure is distributed only at the Bogil-do Island in the southern part of Korea and it appears at various slopes ranging from 5-28 ${ }^{\circ}$, hill ridge slope, sea level altitude lower than $100 \mathrm{~m}$ and comparatively higher altitude of $200 \mathrm{~m}$. (Table 1, Fig. 2). Dryopteris pacifica, Pinus densiflora, and Quercus acuta are the differential species of this association, which can be classified from other study sites. This subassociation is classified into two lower units: Typical variant and Pourthiaea villosa var. villosa variant.

Those lower subunits are distinctively divided into two not only by the difference of differential species but also the altitude lower than $90 \mathrm{~m}$ (typical variant) and the one higher than $200 \mathrm{~m}$ (Pourthiaea villosa var. villosa variant). Pourthiaea villosa var. villosa variant is distributed over north-eastern slope and north-western slope while the typical variant is over various slope aspects. In the Pourthiaea villosa var. villosa variant, the differential species such as Pourthiaea villosa var. villosa, Benthamidia japonica, Carpinus laxiflora, Daphniphyllum macropodum, Dryopteris chinensis, are characterized as the only vegetation structure of Bogil-do Island against the other study sites. The canopy of the typical variant is dominated by Castanopsis sieboldii and Quercus salicina f. angustata while the Pourthiaea villosa var. villosa variant is dominated by Quercus acuta and Castanopsis sieboldii on the canopy.

\subsubsection{Arachniodo-Quercetum salicinae f. angustata}

The vegetation structure is distributed only Jeju-do Island, Korea and various size of rocks forms soil at flat land of $0{ }^{\circ}$ slope (Fig. 3) and it appears at adequate altitude(middle) of 160-315 m (Table 1, Fig. 2). Quercus glauca, Arachniodes aristata, Damnacanthus indicus, and Calanthe discolor is the differential species of this subassociation, which can be classified from the other study sites. This subassociation is classified into two lower units: Mallotus japonicus variant and Typical variant.

Those lower subunits do not show any significant 
differences under basic environmental conditions and were classified by the difference of differential species (flora). Mallotus japonicus variant shows the highest appearing number of species in average, which is classified from other vegetation structures by differential species such as Cyrtomium fortunei, Polystichum lepidocaulon, Mallotus japonicus, and Dryopteris uniformis. The canopy of this variant is mostly dominated by Castanopsis sieboldii but Quercus salicina f. angustata dominates in some relevés. Typical variant is distributed in the study sites in Jeju-do Island. The canopy species are differentiated adequately between the two study sites, even though there is no adequate differences of the character and differential species between the two sites. The canopy of the study site $\operatorname{JIK}(3)$ is dominated by Castanopsis sieboldii, while the one of JIK(4) is dominated by Quercus salicina f. angustata.

\subsection{Hierarchical cluster analysis}

Hierarchical cluster analysis using SYN-TAX 2000 (Podani, 2001) revealed that two units of the community and the association were classified at the level of dissimilarity index $0.389939700 \mathrm{E}+00$ (Fig. 4), and it corresponded with the result of the community units of the phytosociological classification. Low dissimilarities were found between the study sites (relevé groups) composing subassociation of Arachniodo-Quercetum salicinae f. angustata in Jeju-do Island. The index between typical variants of $\operatorname{JIK}(3)$ and JIK(4) was 0.129488600E+00, which was the lowest. The typical variants showed the second lowest dissimilarity index of $0.161286400 \mathrm{E}+00$ with Mallotus japonicus variant (JIK(2)). Such index carries great gap between the indices of other study sites. The dissimilarity index between $\operatorname{SIK}(1)$ and $\operatorname{SIK}(2)$ which correspond with Ardisia japonicaCastanopsis sieboldii community was $0.340025100 \mathrm{E}+00$, and the one between $\operatorname{SIK}(4)$ and $\operatorname{SIK}(5)$ which correspond with Quercetosum acutae subassociation was $0.340025100 \mathrm{E}+00$. The one between $\operatorname{JIK}(1)$ which is the typical subassociation of Ardisia japonica-Castanopsis sieboldii community and the study sites of Arachniodo-Quercetum salicinae f. angustata was revealed to be $0.389939700 \mathrm{E}+00$. The three indics were similar level. Final index between the study sites composing the association of ArdisioCastanopsietum sieboldii was $0.389939700 \mathrm{E}+00$ and the final dissimilarity index at the class level of this Castanopsis sieboldii forest was confirmed as $0.479710800 \mathrm{E}+00$. The results described above are corresponding with those of phytosociological analysis and it proves justification of table manipulation by phytosociological Z-M methodology objectively.

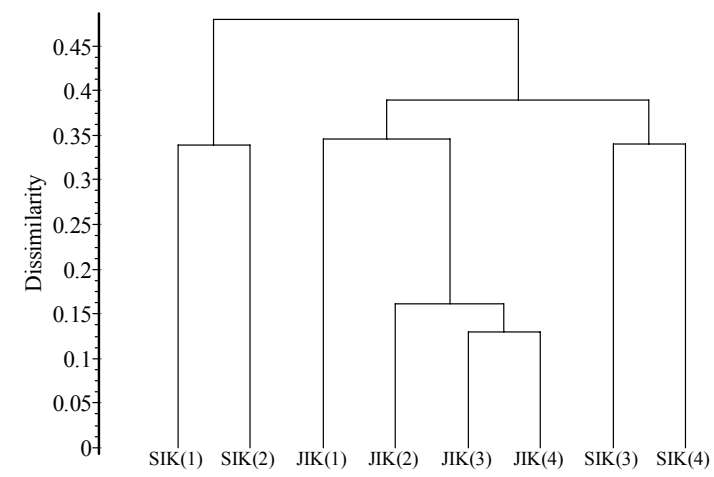

Fig. 4. Hierarchical clustering of Castanopsis sieboldii forest in South Korea.

(Sorting strategy : Average link (UPGMA); Dissimilarity coefficient : Bray-Curtis)

\section{Discussion}

Like the vegetation structure of ArdisioCastanopsietum sieboldii of Japan (Miyawaki and Okuda, 1990), the fact that Quercus acuta, Quercus salicina f. angustata are mixed at the canopy (Quercetosum acutae) and it is distributed over the ridge, coincided with the structure of Japan. Consistency and similarity were also found in the Ardisio-Castanopsietum sieboldii of the two 
neighboring countries in terms that the herbaceous layer such as Dryopteris erythrosora, Dryopteris bissetiana, Hedera rhombea and shrub layer like Cinnamomum tenuifolium, Ilex integra appear.

Ardisio-Castanopsietum sieboldii of the two countries, on the other hand, was classified by the lower unit of subassociation type of Quercetosum acutae but some difference exits in their differential species. Cymbidium goeringii, Quercus acuta appeared in Korea as well but no Osmanthus heterophyllus var. bibracteatus, Elaeagnus glabra was found in Korea. But instead, the subassociation in Korea seemed to be under the edaphic influence according to the appearances of Dryopteris pacifica and Pinus densiflora. High constancy plants of shrub layer in the association of Japan such as Dendropanax trifidus including Osmanthus heterophyllus var. bibracteatus did not appear at Ardisio-Castanopsietum sieboldii in Korea. According to the appearances of the endemic species such as Dendropanax morbiferus appearing in the Korean associations to cope with Dendropanax trifidus in the Japanese associations, the ArdisioCastanopsietum sieboldii of Korea shows floristic characteristics of only Korea.

Some of the species of the vegetation components found in the southern islands in the Korean peninsula are the character and differential species of Pittosporion tobira Nakanishi et H. Suzuki 1974 (Alliance; Miyawaki et al., 1994) of Myrsino-Castanopsietalia sieboldii K. Fujiwara 1981(Miyawaki et al., 1994) of Japan. In the alliance of Japan, there is no association to be named as Castanopsis sieboldii forest by Castanopsis sieboldii et al. dominating the canopy. In this regard, our study call edit as the vegetation components of southern islands in the Korean peninsula along with other components. The Pittosporion tobira is the alliance distributed in the wind confronting area at sea shore (Miyawaki et al., 1994), and some similarity is found considering the study sites with the species of the vegetation components are distributed at low altitude compared with other Castanopsis sieboldii forest of Korea (Fig. 2).

Yun et al.(2011) classified the Castanopsis sieboldii forest as a Castanopsis-Type and confirmed three communities (Castanopsis cuspidata var. sieboldii-Rumohra aristata, Castanopsis cuspidata var. sieboldii-Ardisia japonica, and Castanopsis cuspidata var. sieboldii-Hosta minor communities) in the forest communities of Jeju-do Island and one in the forest communities of Mt. Jiri region. Our study named all the Castanopsis sieboldii (Castanopsis cuspidata var. sieboldii) forest appeared in Jeju-do Island as Ardisio-Castanopsietum sieboldii association, while Yun et al.(2011) named four in their community unit. Castanopsis cuspidata var. sieboldiiArdisia japonica community, similar with the association in our study, lacked in the character species. This result of Yun et al.(2011) was different from our study which found lots of species classifying and characterizing by the units of association, alliance, order and class and it may be reconsidered afterwards. On the other hand, some of the differential species of the other 2 communities corresponded with the character and differential species of the association of our study. The study made classification by an association unit and then classified it into its lower subunits instead of classifying into communities in detail as distinctive naming of upper units was available. Castanopsis cuspidata var. sieboldii-Ligustrum japonicum community is involved in Mt. Jiri region but it may cause misunderstanding in confirming correct distribution of the community because such community found in seashore is named after Mt. Jiri region located inland having different vegetation structures. On the contrary, it may be more precise to name such community after the name of Wan-do and Bogil-do Islands region where various typical evergreen broad-leaved forest of Korean Peninsula is distributed having specific environmental circumstances 
as small islands. character species of above community such as Eurya japonica, Ligustrum japonicum and Cinamomum jaonicum are the character and differential species of the class unit in SIK (study sites) of our study and they were not used as character and differential species of certain community or association unit.

Kil and $\operatorname{Kim}(1999)$ analyzed the vegetation structures of the evergreen broad-leaved forest of Korea by arranging the thesis published previously. Unlike the analysis on the same by our study, they analyzed the vegetation structures of Castanopsis sieboldii forest by Querco-Castanopsion all. nov. and Dendropanaco-Castanopsion sieboldii all. nov.. Quercus acuta and Castanopsis sieboldii, however, carry independent vegetation structure respectively and difference of distributed location by altitudes. The naming with the two species in one community may cause misunderstanding on the vegetation structures of evergreen broad-leaved forest of Korea. Above assertion is proven by the Japanese practice that Castanopsis sieboldii forest does not apply to the names of association and community together even if Quercus acuta is appearing to some extent because the distribution area of two plant species are different. Validity of Dendropanaco-Castanopsion sieboldii needs to be verified by further analysis on its vegetation structure.

Analyzing the vegetation structure system based on those of Japan, this study regards that the one related to Korea carries similarity with Japan by showing difference in the character and differential species of upper units or no appearance but demonstrates unique vegetation structures of Castanopsis sieboldii forest of Korea.

Further vegetation structure analysis, therefore, is required on the distinctive association units for diversified analysis on the vegetation structures through the continuous vegetation investigation and structure analysis of pure Castanopsis sieboldii forest.

\section{Acknowledgements}

This study was partly supported by the National Research Foundation of Korea(NRF) Grant(F012009-000-10022-0).

\section{Reference}

Bailey, R. G., 1990, Ecoregions map of the continents (world map with explanatory supplement), Environm. Consrb., 16, 307-209.

Braun-Blanquet, J., 1964, Pflanzensoziologie. Grundzuge der Vegetationskunde, 3rd ed., SpringerVerlag, Vienna, New York.

BGplants, 2011, http://bean.bio.chiba-u.jp/bgplants/ index.html. Han, B. H., Kim, J. Y., Choi, I. T., Lee, K. J., 2007, Vegetation Structure of Evergreen Broad-Leaved Forest in Dongbackdongsan(Mt.), Jeju-Do, Korea, Kor. J. Env. Eco., 21(4), 335-346.

Kil, B. S., Kim, J. U., 1999, Syntaxonomy of Evergreen Broad-leaved Forests in Korea, Korean J. environ. Biol., 17(3), 233-247.

Kim, C. S., Oh, J. G., 1990, Phytosociological Study on the Evergreen Broad-Leaved Forest in Dadohae National Marine Park-The vegetation of Chodo Archipelago-, Korean J. Ecol., 13(3), 181-190.

Kim, C. S., Oh, J. G., 1991, Phytosociological Study on the Evergreen Broad-Leaved Forest in Dadohae National Marin Park(IV)-The vegetation of Oinarodo Island-, Korean J. Ecol., 14(1), 49-61.

Kim, M. H., 1991, Phytosociological Studies on the Vegetation in Cheju Island -1.Natural CastanopsisMachilus Type Forest, Korean J. Ecol., 14(1), 39-48.

Kolbek, J., Srutek, M., Box, E. O., 2003, Forest vegetation of Northeast Asia, Kluwer Acdemic Publishers, Dordrecht, Netherlands, 7.

Korean Plant Names Index, 2007, http://www.nature. go.kr/kpni/.

Miyawaki, A., Okuda, S., 1990, VEGETATION OF JAPAN ILLUSTRATED, Shibundo Publishers, Tokyo, Japan, 64, 66. 
Miyawaki, A., Okuda, S., Fujiwara, R., 1994, Handbook of Japanese Vegetation, New revised edition, Shibundo, Tokyo.

Mueller-Dombois, D., Ellenberg, H., 1974, Aims and methods of vegetation ecology, John Wiley \& sons, New York, U.S.A..

Oh, K. K., Choi, S. H., 1993, Vegetational Structure and Successional Sere of Warm Temperate Evergreen Forest Region, Korea, Korean J. Ecol., 16(4), 459-476.

Oh, K. K., 1994, Plant Community Structure of Evergreen Broad-Leaved forest in Mt. Turyunsan, Korea, Kor. J. Env. Eco., 8(1), 43-57.

Oh, K. K., Koh, J. G., Kim, T. H., 2007, Altitudinal Distribution of Plant Communities at Donnaeko Valley in the Mt. Hallasan, Kor. J. Env. Eco., 21(2), 141-148.
Park, M. S., 2007, Vegetation of Narodo Islet, Kor. J. Forest Recreation, 11(2), 25-34.

Podani, J., 2001, SYN-TAX2000, Computer program for data analysis in ecological and systematics, Budapest, 53.

Water, H., Box, E. O., 1976, Global classification of natural terrestrial ecosytems, Vegetatio, 32, 75-81.

Walter, H., 1984, Vegetation of the Eearth. 3rd ed. Springer Verlag, New York, U.S.A., 318.

Yanai, A., Kyo, K., Ohno, K., 2007, Landscape ecological studies on structural analysis of urban green areas, Landscape Ecology and Management, 11(2), 73-91.

Yun, J. H., Hukusima, T., Kim, M. H., Yoshikawa, M., 2011, The Comparative Studies on the Distribution and Species composition of Forest community in Korea and Japan around the East Sea, Kor. J. Env. Eco., 23(3), 327-357. 